\title{
目
}

Arch. Min. Sci. 62 (2017), 3, 639-652

Electronic version (in color) of this paper is available: http://mining.archives.pl

DOI 10.1515/amsc-2017-0046

PAWEŁ WRONA*\#

\section{THE INFLUENCE OF CLIMATE CHANGE ON $\mathrm{CO}_{2} \mathrm{AND} \mathrm{CH}_{4} \mathrm{CONCENTRATION} \mathrm{NEAR}$ CLOSED SHAFT - NUMERICAL SIMULATIONS}

\author{
WPLYW ZMIANY KLIMATU NA ROZKLAD STĘŻEŃ $\mathrm{CO}_{2}$ I CH$_{4}$ WOKÓŁ \\ NIECZYNNEGO SZYBU - SYMULACJE NUMERYCZNE
}

Given the scientific consensus pointing to climate change, the more extreme weather events associated with this will lead to deeper pressure drops. As has already been stated, pressure drops are the main cause of gas flow from underground sites to the surface. This article presents the results of numerical simulations of the change in distribution of $\mathrm{CO}_{2}$ and $\mathrm{CH}_{4}$ near a closed mining shaft under the predicted baric tendency. Simulations have been undertaken by means of the FDS software package with the Pyrosim graphical interface - a CFD tool for fire and ventilation analysis. Assumptions have been based on previous results of in-situ measurements. The results (determined for a height of $1 \mathrm{~m}$ above the ground) were compared to the following levels (later in the text comparison levels): for $\mathrm{CO}_{2} 0.1 \%$ vol. according to Pettenkoffer's scale and $2.5 \%$ vol. for $\mathrm{CH} 4$ as the half of Lower Explosive Limit (LEL). The results show that the deeper baric drops anticipated could lead to a wider spread of both greenhouse gases in the vicinity of the shaft, especially along the prevailing wind direction. According to the results obtained, $\mathrm{CO}_{2}$ and $\mathrm{CH}_{4}$ with concentrations above their comparison levels are expected at a distance greater than $50 \mathrm{~m}$ from the shaft when wind is present for $\mathrm{CO}_{2}$ and at a distance of $4.5 \mathrm{~m}$ for $\mathrm{CH}_{4}$. Subsequent analysis of the results enabled the determination of functions for describing the concentration of gases along the wind direction line under the projected pressure drop. The results relate to a particular case, although the model could easily be modified to any other example of gas emissions from underground sites.

Keywords: greenhouse gas emissions, climate change, mine closure, abandoned shaft, underground gas storage, public safety, CFD

Wraz ze zmianami klimatu należy spodziewać się większej niż obecnie liczby dni w roku, w których będą występować ekstremalne zjawiska pogodowe, związane z przechodzeniem coraz głębszych frontów atmosferycznych (np. Falarz, 1997; Koźmiński i Michalska, 2010). Przyczyni się to do wzrostu tendencji barycznej zniżek ciśnienia. Zniżki baryczne są główną przyczyną emisji gazów kopalnianych na powierzchnię (Wrona et al., 2016b). Gazy te zawierają głównie $\mathrm{CO}_{2}$ i $\mathrm{CH}_{4}$, które są uznawane za gazy cieplarniane oraz mogą stworzyć lokalne zagrożenie dla bezpieczeństwa powszechnego (np. Czaja, 2012).

* SILESIAN UNIVERSITY OF TECHNOLOGY, UL. AKADEMICKA 2, 44-100 GLIWICE,POLAND

\# Corresponding author: Pawel.Wrona@polsl.pl 
W artykule przedstawiono wyniki symulacji numerycznych dotyczących zmiany stężenia obu gazów emitowanych z nieczynnego szybu górniczego na skutek zwiększającej się zniżkowej tendencji barycznej. Na podstawie analizy literaturowej zagadnienia (np. Falarz, 1997), stwierdzono, że w przyszłości możliwe są ekstremalne zniżki baryczne sięgające lub nawet przekraczające $5 \mathrm{hPa} / 1 \mathrm{~h}$. Na obszarze południowej Polski można spodziewać się raz na dwa lata zniżki sięgającej $4 \mathrm{hPa} / 1 \mathrm{~h}$ oraz raz na 10 lat przekraczającej $5 \mathrm{hPa} / 1 \mathrm{~h}$. Takie zdarzenie, spowodowane przez zmiany klimatu, może doprowadzić do intensywniejszego wypływu gazów z obszarów podziemnych, a przez to zasięg ich oddziaływania może być zaskakujący i przede wszystkim niebezpieczny dla okolicznej ludności. Równocześnie do atmosfery zostanie wyemitowana większa ilość gazów cieplarnianych.

Natężenie emisji gazów przyjęte podczas symulacji oparto o wyniki pomiarów in-situ nad jednym z nieczynnych szybów na Górnym Śląsku (Wrona et al., 2016b), kiedy to wyznaczono empiryczną zależność (1) pomiędzy wartością tendencji zniżki barycznej, a natężeniem wypływu gazów przez szyb. Założono także stężenia obu gazów jako 5\%obj. Wartości te określono jako prawdopodobne na podstawie przeprowadzonych wcześniej pomiarów (Wrona et al., 2016b), oraz na podstawie analizy literaturowej (np. Nawrat, 2002; Szlązak et al., 2002; Krause, 2003). Założono kilka wariantów (zestawów danych wejściowych) symulacji. Dotyczyły one zmiennej wartości tendencji barycznej (TB) oraz wpływu wiatru z jednego kierunku geograficznego (zachodu).Wyznaczone wartości zostały określone na wysokości $1 \mathrm{~m}$ nad gruntem. Wykazano, że przy bezwietrznej pogodzie, wraz ze wzrostem tendencji barycznej do wartości $5 \mathrm{hPa} / 1 \mathrm{~h}$ zasięg obecności $\mathrm{CO}_{2}$ w stężeniu przekraczającym $0.1 \%$ obj. (wartość po przekroczeniu której można odnotować efekt duszący, wg skali Pettenkoffera), sięga $45 \mathrm{~m}$. Dla metanu przyjęto poziom porównawczy jako $2.5 \%$ obj. stanowiący połowę dolnej granicy wybuchowości tego gazu i stwierdzono, że stężenie wyższe od tej wartości występuje do $4 \mathrm{~m}$ od szybu.

Przy wietrze $5 \mathrm{~m} / \mathrm{s}$ z zachodu i $\mathrm{TB}=1 \mathrm{hPa} / 1 \mathrm{~h}$ wartości NDS w linii wiatru (E) są przekroczone do $50 \mathrm{~m}$ dla $\mathrm{CO}_{2}$ i $4.2 \mathrm{~m}_{\text {dla } \mathrm{CH}_{4}}$ (Rys. 6,7). Natomiast przy prognozowanej zniżce $5 \mathrm{hPa} / 1 \mathrm{~h}$ wartość NDS dla $\mathrm{CO}_{2}$ w linii jest przekroczona na ponad $50 \mathrm{~m}$ od szybu, a dla $\mathrm{CH}_{4}$ na $4.5 \mathrm{~m}$ (Rys. 8,9)

Prognozę dotyczącą zmiany stężenia na linii zgodnej z dominującym kierunkiem wiatru przedstawiono na rysunkach $10 \mathrm{i} 11$, podano funkcje aproksymujące i współczynnik determinacji wykonanej prognozy (2) i (3). Wykazano, że przy spodziewanej na skutek zmian klimatu zniżce barycznej sięgającej $5 \mathrm{hPa} / 1 \mathrm{~h}$ oba gazy mogą być obecne w odległości ponad $100 \mathrm{~m}$ od szybu na wysokości $1 \mathrm{~m}$ nad gruntem.

Uzyskane wyniki wskazują na możliwość występowania w przyszłości poważniejszego niż obecnie zagrożenia gazowego wokół nieczynnych szybów, a także zwiększonej emisji gazów cieplarnianych do atmosfery.

Zbudowany model może być łatwo modyfikowany do innych przypadków emisji gazów z górotworu, np. przy rozszczelnieniu instalacji CCS lub UCG, a także przy wszelkich stanach awaryjnych systemów odmetanowania.

Słowa kluczowe: emisja gazów cieplarnianych, zmiana klimatu, likwidacja kopalń, nieczynny szyb, lokowanie podziemne gazów, bezpieczeństwo, CFD

\section{Introduction}

The problem of gas leakage from underground sites does not only relate to abandoned coal mines. It is also possible when other underground operations take place e.g. as a result of some break down or emergency situation during, for example, carbon capture and storage (CCS), gas drainage, underground coal gasification (UCG) etc. (Lewicki et al., 2007; Bateson et al., 2008; Paulley et al., 2013; Wrona et al., 2016b). It is generally stated that the main migration pathways of gas leakage would be along shafts, boreholes and faults (e.g. Annunziatellis et al., 2008; Wrona, 2016 b).

Pressure drops are the main factor causing gas emissions from underground sites (Lagny et al., 2014; Wrona, 2015; Wrona et al., 2016b). Considering the results previously obtained (Wrona, 2010a, 2010b; Wrona et al., 2016b), the thermal buoyancy effect and changes in gas mixture composition only marginally influence the rate of emissions. 
Methane and carbon dioxide $\left(\mathrm{CH}_{4}\right.$ and $\left.\mathrm{CO}_{2}\right)$ are the most common among the expected gases (Creedy, 1993; Prokop, 2001; Kotarba et al., 2002; Dziurzyński et al., 2004, Rudakov et al., 2014). They are both considered to be greenhouse gases.

Climate change is likely to result in a greater intensity and frequency of storms associated with deep low-pressure systems (Falarz, 1997; Ustrnul \& Czekierda, 2000; Trepińska, 2007). Barometric pressure drops will thereby increase in frequency and magnitude during severe weather events (NGER, 2007; Collins et al., 2013). In addition, a greater number of days with low pressure are also expected.

These more extreme atmospheric events and, consequently, deeper pressure drops could lead to more gas emissions from underground mines (Lagny et al., 2014; Wrona et al., 2016b).

Future projections of maximal pressure tendency for Polish territory can be computed based on e.g. (Falarz, 1997; Bielec-Bąkowska, 2007; Koźmiński \& Michalska, 2010).

Maximal 24h pressure changes (drops) over the period 1986-2007 varied during the winter between $966.1 \mathrm{hPa}$ and $1049.4 \mathrm{hPa},(3.47 \mathrm{hPa} / 1 \mathrm{~h})$, and during the summer between 990.7 and $1031.5 \mathrm{hPa}(1.7 \mathrm{hPa} / 1 \mathrm{~h})$ (Falarz, 1997; Koźmiński \& Michalska, 2010). There were 23 days of the year with intense low pressure (pressure in the center of a baric system was from $945 \mathrm{hPa}$ to $985 \mathrm{hPa}$ ) and 11 days with strong high pressure (pressure in the center of a baric system was from $1040 \mathrm{hPa}$ to $1050 \mathrm{hPa}$ (Bielec-Bakowska, 2007). A detailed analysis for southern Poland (near The Upper Silesia Region) has been conducted by Falarz (Falarz, 1997). Considering the Kraków area, she stated that in the future a significant pressure drop $4 \mathrm{hPa} / 1 \mathrm{~h}$ or even $5 \mathrm{hPa} / 1 \mathrm{~h}$ should be expected at least once every 2 years, mainly in January. Once in every 10 years the pressure drop could exceed $5 \mathrm{hPa} / 1 \mathrm{~h}$, also in January.

This statement served as the basis for the simulations presented in this article.

Over the three year period in which measurements were taken above the closed Gliwice II shaft, readings indicated that the rate of $\mathrm{CO}_{2}$ emissions varied from 12.7 to $162.3 \mathrm{~kg}_{\mathrm{CO}_{2}} / \mathrm{h}$. The maximal detected concentration of $\mathrm{CO}_{2}$ in the gas mixture was $3.24 \mathrm{vol} \%$ (Wrona et al., 2016b). Carbon dioxide was detected up to $43 \mathrm{~m}$ from the shaft. In the southern part of the Upper Silesian Coal Basin (e.g. Moszczenica coal mine), methane concentrations in outflowing gases through abandoned shafts were as high as 3.4\%vol. (according to Grzybek (Grzybek, 2012)), and up to a lower explosive limit (5\%vol) at the Morcinek coal mine where an explosion had taken place (Nawrat, 2002). Methane hazard was also detected in abandoned 1 Maja coal mine (Krause, 2003; Grzybek, 2012).

Therefore, this article presents the results of numerical simulations of changes of $\mathrm{CO}_{2}$ and $\mathrm{CH}_{4}$ concentrations in vicinity of a closed shaft (up to $50 \mathrm{~m}$ from the well and $1 \mathrm{~m}$ above the ground) according to the predicted maximal pressure drop. Two sets of the parameters (later in the text: sets) were checked. The first set did not include wind speed. The second set included a wind speed of $5 \mathrm{~m} / \mathrm{s}$ from the west. The results (determined for a height of $1 \mathrm{~m}$ above the ground) were compared to the following levels: for $\mathrm{CO}_{2} 0.1 \%$ vol. according to Pettenkoffer's scale (Słomka, 1999) and 2.5\%vol. for $\mathrm{CH}_{4}$ as the half of Lower Explosive Limit. The results could be treated as a forecast due to this particular site, although the model can easily be modified to other cases, such as leakage from a CCS installation or methane drainage system, breakdown of an underground coal gasification system, etc. 


\section{The model}

Numerical simulation is useful tool for air flow examinations (e.g. Branny, 2003). The simulations were conducted using FDS software, which belongs to the group of Computational Fluid Dynamics (CFD) programs and is based on numerical solutions of fluid mechanics equations. This software has already been applied for the simulation of gas flow in underground excavations or in the tunnels (e.g. Wrona, 2013; Wrona et al., 2013; Suban 2015; Wrona et al., 2016a). The model has been validated by the National Institute of Standards and Technology, USA (McGrattan et al., 2010).

\subsection{Overlay}

For consideration of fluid flow, the algorithm of FDS is based on a numerical solutions of the Navier - Stokes equations for each node of the calculation grid and with approximation of the obtained results between the points for every subsequent iteration. The partial derivatives of the conservation equations of mass, momentum and energy are approximated as finite differences, and the solution is updated in time on a three-dimensional, rectilinear grid. The equation of state is also considered (McGrattan et al., 2010).

FDS numerically solves a form of the Navier-Stokes equations appropriate for low speed flow. The core algorithm is an explicit predictor-corrector scheme that is second order accurate in space and time. Turbulence is treated by means of the Smagorinsky form of Large Eddy Simulation (LES). It is possible to perform a Direct Numerical Simulation (DNS) if the numerical grid is fine enough. LES is the default mode of operation and is based on approximation of the influence of small vortices (which are independent from flow geometry) and inputting them into calculations as additional tensors and then solving the model only for large vortexes which depend on geometry and boundary conditions (Anderson et al., 1997; McGrattan et al., 2010).

In order to reduce the calculation time, the mathematical model applied in FDS contains various simplifications. The most important for the flow are listed below:

a) low speed flow (low Mach number),

b) structured, uniform, staggered grid,

c) constant turbulent Schmidt and Prandtl numbers (McGrattan et al., 2010).

\subsection{Assumptions}

\section{a) Geometry}

The flat area near the closed shaft was constructed (Fig. 1). The width and length was $200 \mathrm{~m}$ ( $\mathrm{X}$ and $\mathrm{Y}$ axis) and the height was $50 \mathrm{~m}$ ( $\mathrm{Z}$ axis). The shaft was located in the middle of this structure. The cross-section area of the shaft was $1 \mathrm{~m}^{2}$.

b) Mesh

The mesh was $200 \mathrm{~m} \times 200 \mathrm{~m} \times 50 \mathrm{~m}$ and the dimension of one cell was $0.62 \mathrm{~m}$, giving 8192000 cells in the entire domain.

c) Physics and Solver settings

The Large Eddy Simulation (LES) method was selected for the simulations. Boundaries were defined as Inflow and Outflow surfaces (Opened), except for the wind set, where the western open surface was changed into the Velocity Inlet. The velocity was set as $5 \mathrm{~m} / \mathrm{s}$ with a cylindri- 


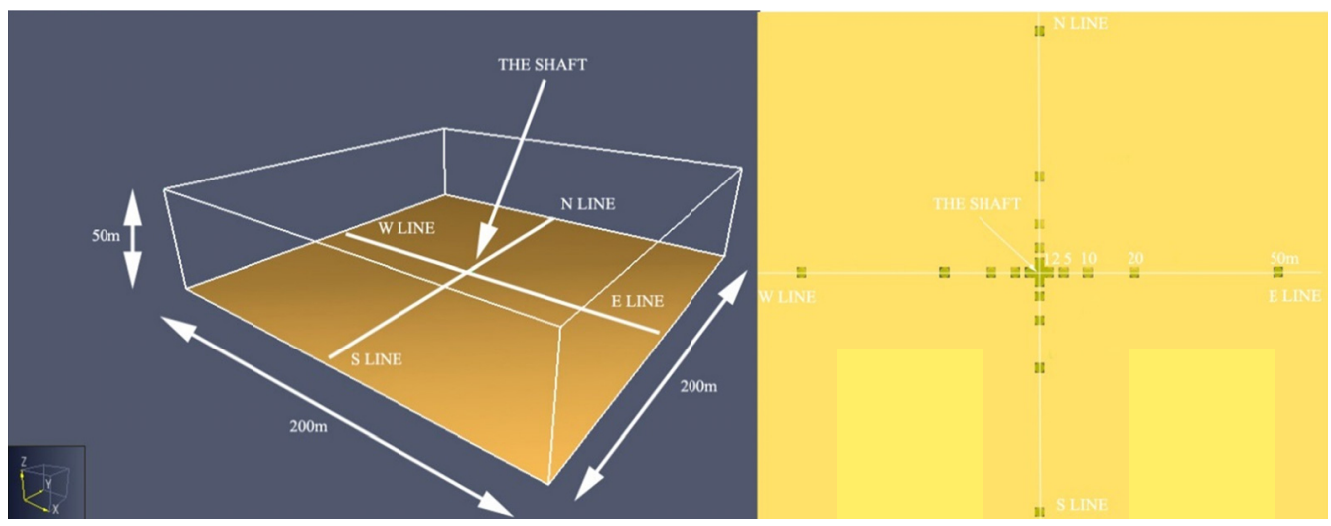

Fig. 1. Overlay of the model (on the left). Location of virtual sensors (on the right)

cal wind profile. Emissions were set as Mass Flow Outlet and were located at the surface of the shaft. Concentrations of $\mathrm{CO}_{2}$ and $\mathrm{CH}_{4}$ were set as $5 \%$ vol. (for methane it is a lower explosive limit). Probable concentrations were assumed on the basis of measuring data and from consulting the literature (Nawrat, 2002; Krause, 2003; Grzybek, 2012; Wrona et al., 2016b). The gas temperature was $12^{\circ} \mathrm{C}$, whereas the ambient temperature was $20^{\circ} \mathrm{C}$. The temperature gradient in the atmosphere was $0.06^{\circ} \mathrm{C} / 1 \mathrm{~m}$, gravity according to $\mathrm{Z}$ axis. The simulation time was 120 seconds.

d) Velocity of emissions and assumed sets of parameters

As previously stated when discussing the in situ measurements (Wrona et al., 2016b) there is an empirical, linear function $\left(R^{2}=0.812\right)$ which can describe the relation between baric tendency (determined as a change of pressure for one hour) and emissions rate (1):

$$
V=0.902(T B)+0.026
$$

where:

$V$ - gas emissions, $\mathrm{m}^{3} / \mathrm{s}$,

$T B-1 \mathrm{~h}$ baric tendency, $\mathrm{hPa} / 1 \mathrm{~h}$.

Equation (1) was determined for the range of TB between $0.1 \mathrm{hPa}$ and $0.8 \mathrm{hPa}$. Then it was extrapolated.

Assuming equation (1) and a cross-section shaft area of $1 \mathrm{~m}^{2}$, the following parameters were set:

- Wind $0,0 \mathrm{~m} / \mathrm{s}, T B=1,0 \mathrm{hPa} / 1 \mathrm{~h}$, velocity of emissions, $w=0.91 \mathrm{~m} / \mathrm{s}$.

- Wind $0,0 \mathrm{~m} / \mathrm{s}, T B=2,0 \mathrm{hPa} / 1 \mathrm{~h}$, velocity of emissions, $w=1.83 \mathrm{~m} / \mathrm{s}$.

- Wind $0,0 \mathrm{~m} / \mathrm{s}, T B=3,0 \mathrm{hPa} / 1 \mathrm{~h}$, velocity of emissions, $w=2.73 \mathrm{~m} / \mathrm{s}$.

- Wind $0,0 \mathrm{~m} / \mathrm{s}, T B=5,0 \mathrm{hPa} / 1 \mathrm{~h}$, velocity of emissions, $w=4,53 \mathrm{~m} / \mathrm{s}$.

- Wind $5,0 \mathrm{~m} / \mathrm{s} T B=1,0 \mathrm{hPa} / 1 \mathrm{~h}$, velocity of emissions, $w=0.91 \mathrm{~m} / \mathrm{s}$.

- Wind $5,0 \mathrm{~m} / \mathrm{s} T B=5,0 \mathrm{hPa} / 1 \mathrm{~h}$, velocity of emissions, $w=4.53 \mathrm{~m} / \mathrm{s}$.

e) Postprocessing

Detailed results were obtained at data sheets and plots which were read from virtual gas sensors located at each main geographic directions (Fig. 1) (assigned later in the text as N line, $\mathrm{S}$ line, E line, W line) at distances of $1 \mathrm{~m}, 2 \mathrm{~m}, 5 \mathrm{~m}, 10 \mathrm{~m}, 20 \mathrm{~m}$ and $50 \mathrm{~m}$ respectively from the shaft. They were located at a height of $1 \mathrm{~m}$ above the ground. The results from the data plots were 
taken from the time period between 100s and 120s and then were averaged. This was the basis for constructing the diagrams (Figs 2-11).

\section{The results and discussion}

The results are presented according to the sets of parameters listed in previous section. The first 4 sets were based on zero wind influence and the last two sets were fixed to compare different rate of emissions under a $5 \mathrm{~m} / \mathrm{s}$ wind influence.

\subsection{Wind velocity $0.0 \mathrm{~m} / \mathrm{s}$}

According to a wind velocity set at $0 \mathrm{~m} / \mathrm{s}$, the results for the two different gases are comparable in each direction. Examining detailed results reveals only a slight difference in $\mathrm{CO}_{2}$ and $\mathrm{CH}_{4}$ concentrations at different measuring points, e.g. at $20 \mathrm{~m}$ from the shaft $\mathrm{CO}_{2}=0.38 \% \mathrm{vol}$. and $\mathrm{CH}_{4}=0.40 \%$ vol.

The differences are caused by CFD modeling which is based on the assumption that the fluctuations associated with turbulence are random. The randomly changing variables are considered to be made up of a time average plus a fluctuation. Assumed turbulent model is solved by LES method. The principal idea behind LES is to reduce the computational cost by ignoring the smallest length scales, which are the most computationally expensive to resolve, via lowpass filtering of the Navier-Stokes equations. Such a low-pass filtering, which can be viewed as a time - averaging and spatial - averaging.

Looking at Figures 2-4 and detailed results from the data plots further observations were made. Red lines in Figures 2-4 indicate assumed comparison levels.

Concentrations of both gases, under the projected climate change and the most intense $T B=5 \mathrm{hPa} / 1 \mathrm{~h}$ at a distance of $50 \mathrm{~m}$, are very close to $0 \% \mathrm{vol}$. For $\mathrm{CH}_{4}$ it equals $4.98 \mathrm{e}-36 \mathrm{~mol} / \mathrm{mol}$ in fact. For $\mathrm{CO}_{2}$ it equals $4.8 \mathrm{e}-36 \mathrm{~mol} / \mathrm{mol}$. In other cases, the concentrations are $0 \mathrm{~mol} / \mathrm{mol}$ (according to the assumptions of the model). Thus they were set as $2 \mathrm{ppb}$ for $\mathrm{CH}_{4}$ and $0.04 \%$ vol. for $\mathrm{CO}_{2}$.

Maximal $\mathrm{CO}_{2}$ concentration at the $\mathrm{N}$ line (Fig. 2) was $4.9 \%$ vol. at a distance of $1 \mathrm{~m}$ from the. Maximal $\mathrm{CH}_{4}$ concentration at the $\mathrm{N}$ line was also $4.9 \%$ vol. at $1 \mathrm{~m}$ from the shaft. Estimated comparison level for $\mathrm{CO}_{2}$ is exceeded up to $40-45 \mathrm{~m}$ from the shaft for $T B=5 \mathrm{hPa} / 1 \mathrm{~h}$ for $\mathrm{CH}_{4}$ up to $4 \mathrm{~m}$ for $T B=5 \mathrm{hPa} / 1 \mathrm{~h}$.

Maximal $\mathrm{CO}_{2}$ concentration at the $\mathrm{E}$ line (Fig. 3) was $4.9 \%$ vol. at $1 \mathrm{~m}$ from the shaft. Maximal $\mathrm{CH}_{4}$ concentration at the $\mathrm{E}$ line was also $4.9 \%$ vol. at $1 \mathrm{~m}$ from the shaft. Estimated comparison level for $\mathrm{CO}_{2}$ is exceeded up to $40-45 \mathrm{~m}$ from the shaft for and for $\mathrm{CH}_{4}$ up to $4 \mathrm{~m}$.

Maximal $\mathrm{CO}_{2}$ concentration at the $\mathrm{W}$ line (Fig. 4) was $4.9 \%$ vol. at a distance of $1 \mathrm{~m}$ from the shaft. Maximal $\mathrm{CH}_{4}$ concentration at the $\mathrm{W}$ line was also $4.9 \%$ vol. at $1 \mathrm{~m}$ from the shaft. Estimated comparison level for $\mathrm{CO}_{2}$ is exceeded up to $45 \mathrm{~m}$ from the shaft and for $\mathrm{CH}_{4}$ up to $4 \mathrm{~m}$ for $T B=3 \mathrm{hPa} / 1 \mathrm{~h}$.

Maximal $\mathrm{CO}_{2}$ concentration at the S line (Fig. 5) was $4.9 \%$ vol. at a distance of $1 \mathrm{~m}$ from the shaft. Maximal $\mathrm{CH}_{4}$ concentration at the $\mathrm{W}$ line was also $4.9 \%$ vol. at $1 \mathrm{~m}$ from the shaft. Estimated comparison level for $\mathrm{CO}_{2}$ is exceeded up to $45 \mathrm{~m}$ from the shaft and for $\mathrm{CH}_{4}$ up to $4 \mathrm{~m}$.

The general conclusion for assumed sets with no wind is that, for the more intense $T B$ values of $3 \mathrm{hPa} / 1 \mathrm{~h}$ and $5 \mathrm{hPa} / 1 \mathrm{~h}$, assumed comparison levels for both greenhouse gasses could be 


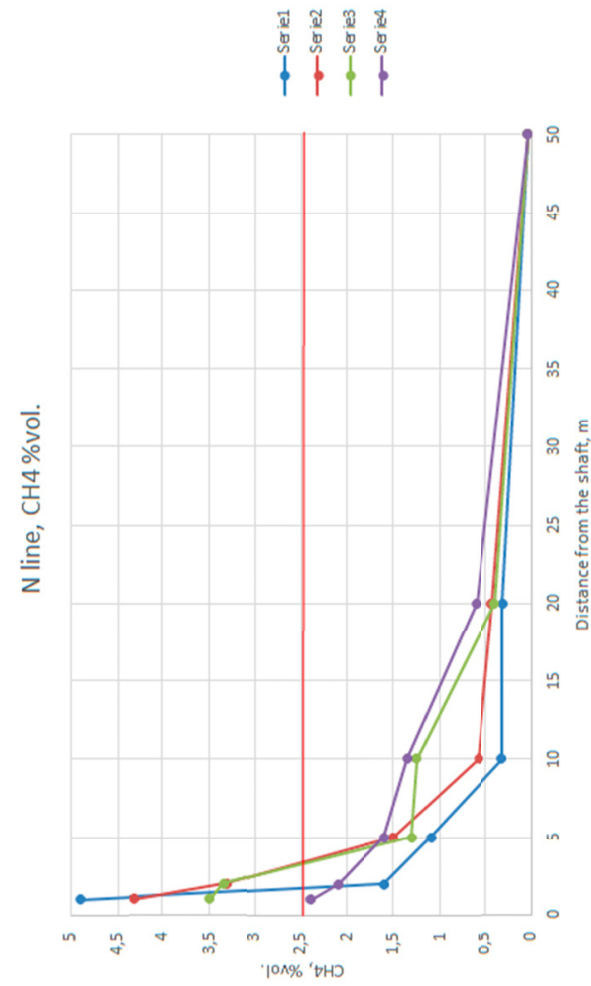

I
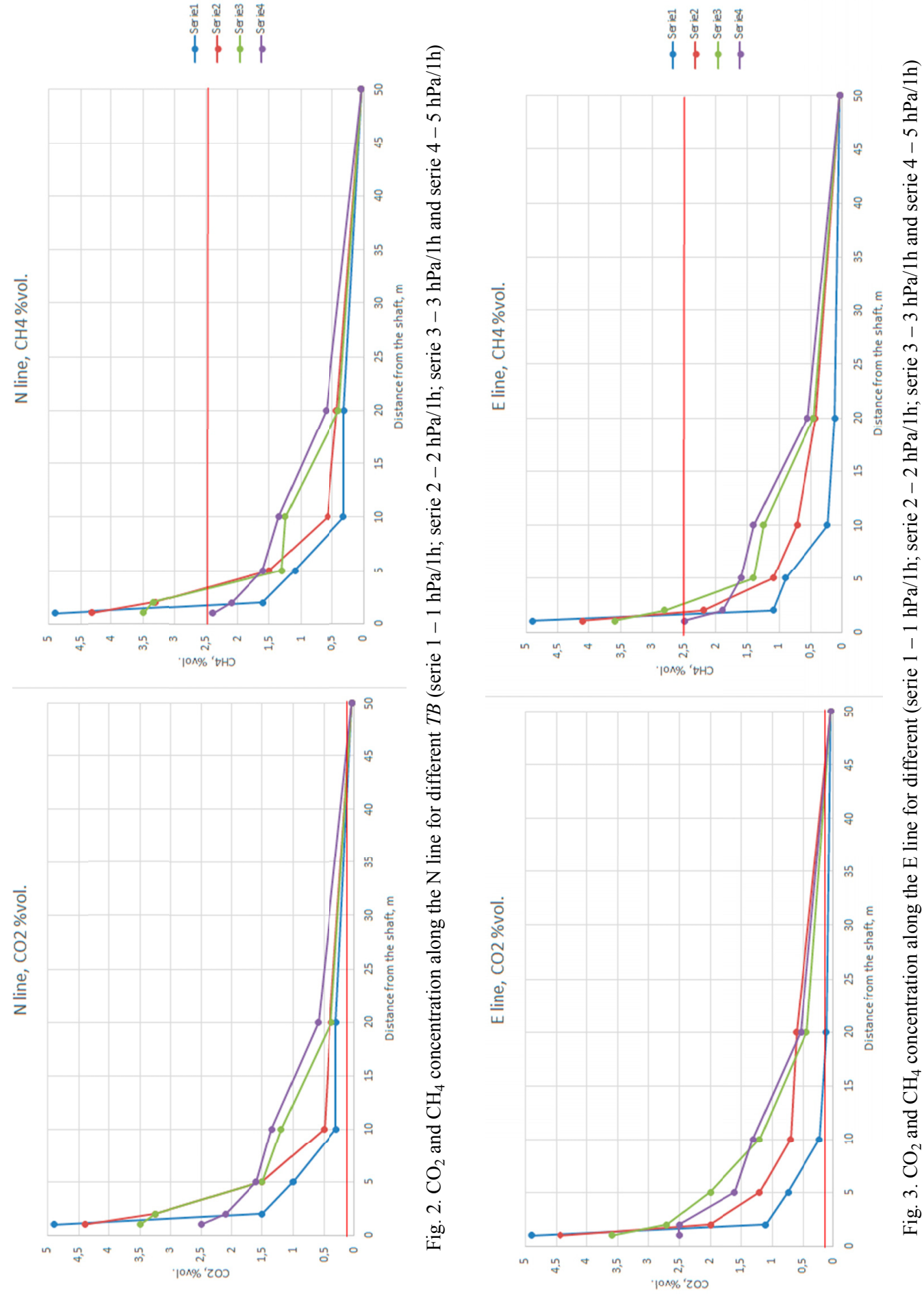


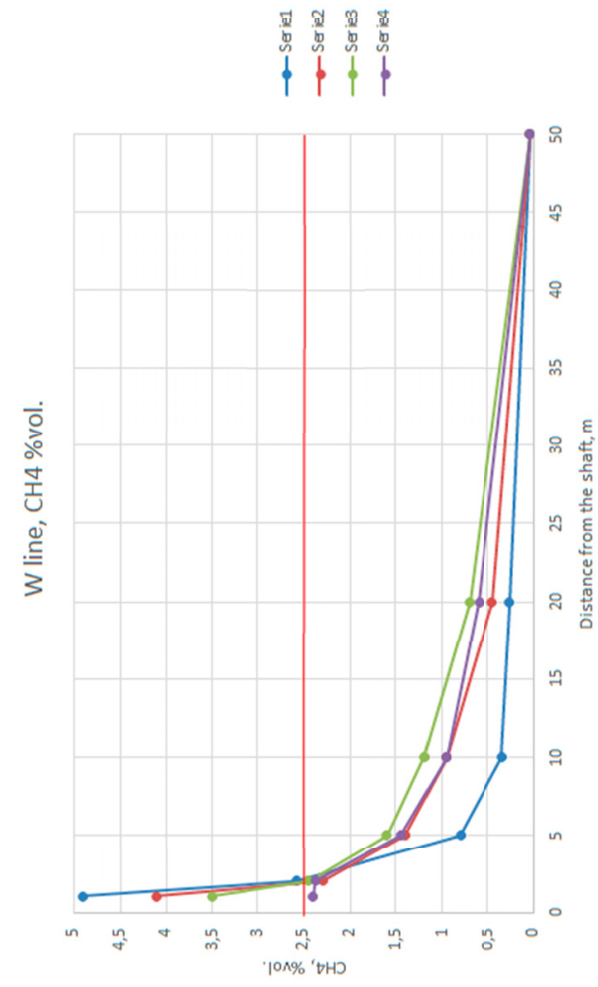

政
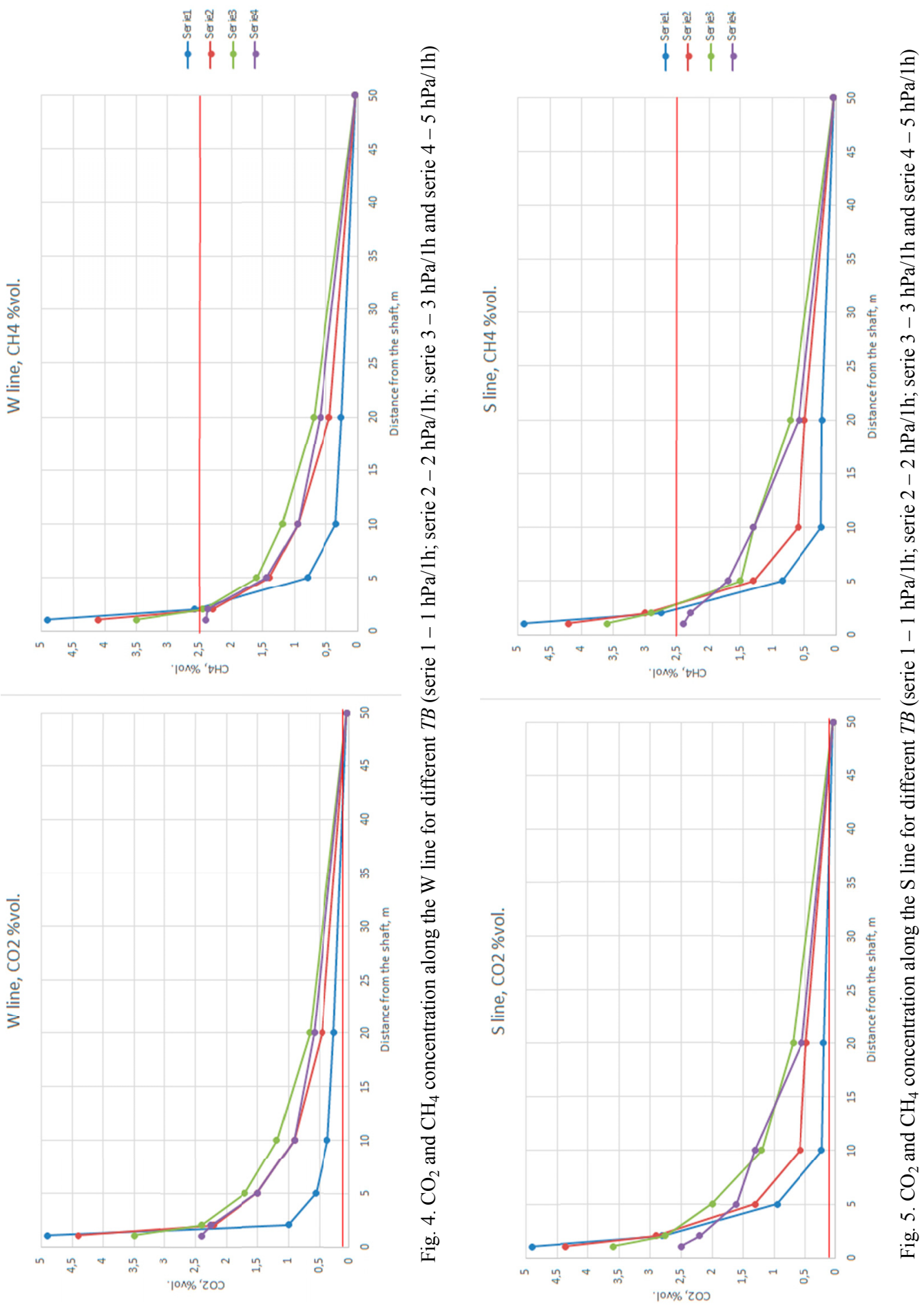
exceeded at a greater distance from the shaft. This distance is up to $45 \mathrm{~m}$ for $\mathrm{CO}_{2}$ and $4 \mathrm{~m}$ for $\mathrm{CH}_{4}$. It could be also observed that up to approx. 5-10 m from the shaft TB $5 \mathrm{hPa} / 1 \mathrm{~h}$ results in smaller concentration of the gases than $T B 3 \mathrm{hPa} / 1 \mathrm{~h}$. It is probably caused by higher velocity of emissions which transport the gases higher in close vicinity of the shaft.

\subsection{Wind influence}

Two examples are presented. The first is when the baric tendency is $1 \mathrm{hPa} / 1 \mathrm{~h}$, a westerly wind is blowing with velocity $w=5.0 \mathrm{~m} / \mathrm{s}$. This is a typical ongoing situation near a closed shaft. The second example is a projection taking into account climate change extrapolations, where TB would rise up to $5 \mathrm{hPa} / \mathrm{h}$.

The westerly wind $(5 \mathrm{~m} / \mathrm{s})$ causes a significant gas flow in an easterly direction, although gas is also detected in the vicinity of the shaft at other directions. Assumed comparison level for $\mathrm{CO}_{2}$ at $\mathrm{E}$ line is exceeded up to $50 \mathrm{~m}$ from the shaft, and for $\mathrm{CH}_{4}$ up to $4.3 \mathrm{~m}$ for $T B=1 \mathrm{hPa} / 1 \mathrm{~h}$ (Fig. 6). Nevertheless, it should be noted that the concentration of both gases at the $\mathrm{E}$ line is slightly higher than $0 \% \mathrm{vol}$. at a distance of $50 \mathrm{~m}$, whereas for other lines it reaches zero about $5 \mathrm{~m}$ from the shaft.

In the case of $T B=5 \mathrm{hPa} / \mathrm{h}$ gas is also observed in the vicinity of the shaft along all the lines. Although comparison level for $\mathrm{CO}_{2}$ is exceeded over $50 \mathrm{~m}$ from the shaft and that for $\mathrm{CH}_{4}$ about $4.5 \mathrm{~m}$ away. However, it should be also noted that the concentration of both gases at the $\mathrm{E}$ line in this case is significantly higher than $0 \% \mathrm{vol}$. at a distance of $50 \mathrm{~m}$, whereas for other lines it reaches zero about $5 \mathrm{~m}$ from the shaft, as in the previous case (Fig. 7).

\subsection{Comparison at $\mathrm{E}$ line for wind $0 \mathrm{~m} / \mathrm{s}$ and $5 \mathrm{~m} / \mathrm{s}$}

Results for the E line were compared for the sets with and without wind influence (Fig. 8, 9). Analyzing Figures 8 and 9 it is clear that wind influence is significant. It is also clear that $T B=5 \mathrm{hPa} / 1 \mathrm{~h}$ produces higher concentration of both gases along this direction.

Analyzing Figures 10 and 11 , the following relations could be estimated. For $T B=5 \mathrm{hPa} / 1 \mathrm{~h}$, the concentration of $\mathrm{CO}_{2}$ along the wind direction line can be given as an approximate function (2) $\left(\mathrm{y}-\mathrm{CO}_{2} \%\right.$ vol. $\mathrm{x}$ - distance from the shaft (d))

$$
\mathrm{CO}_{2}=4.2755 d^{-0.581}
$$

where:

$\mathrm{CO}_{2}$ - carbon dioxide concentration, \%vol.,

$d$ - distance from the shaft, $\mathrm{m}$.

and $R^{2}=0.975$.

For $T B=5 \mathrm{hPa} / 1 \mathrm{~h}$, the concentration of $\mathrm{CH}_{4}$ along the wind direction line can be given as an approximate function (3) where (y- $\mathrm{CH}_{4} \% \mathrm{vol} . \mathrm{x}$ - distance from the shaft (d)).

$$
\mathrm{CH}_{4}=3.649 d^{-0.47}
$$

where:

$\mathrm{CH}_{4}$ - methane concentration, \%vol.,

$d$ - distance from the shaft, $\mathrm{m}$.

and $R^{2}=0.9568$. 

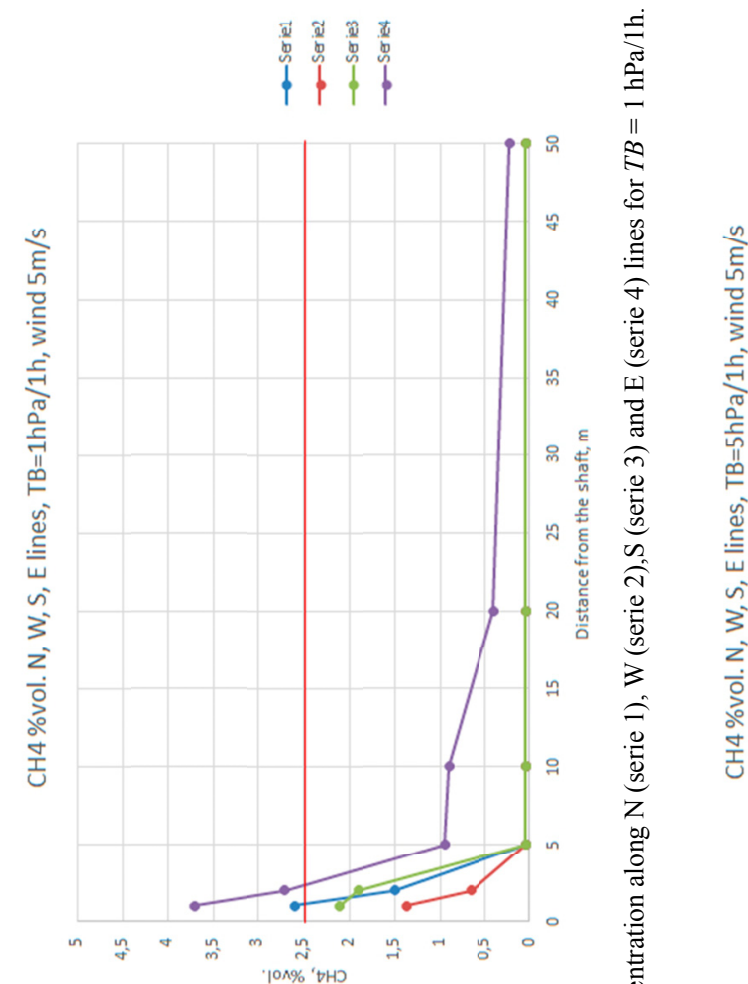

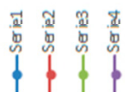
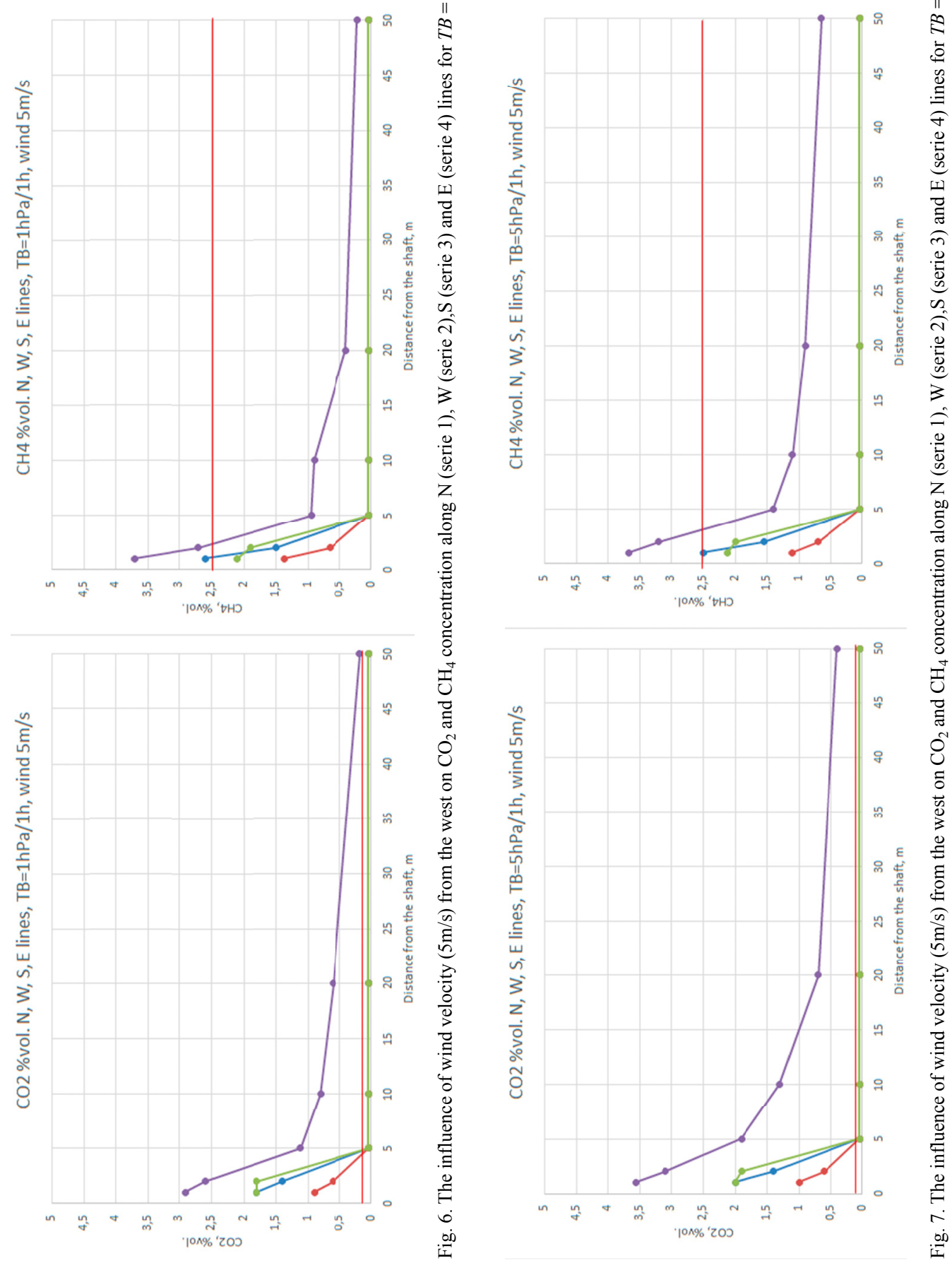
㳯
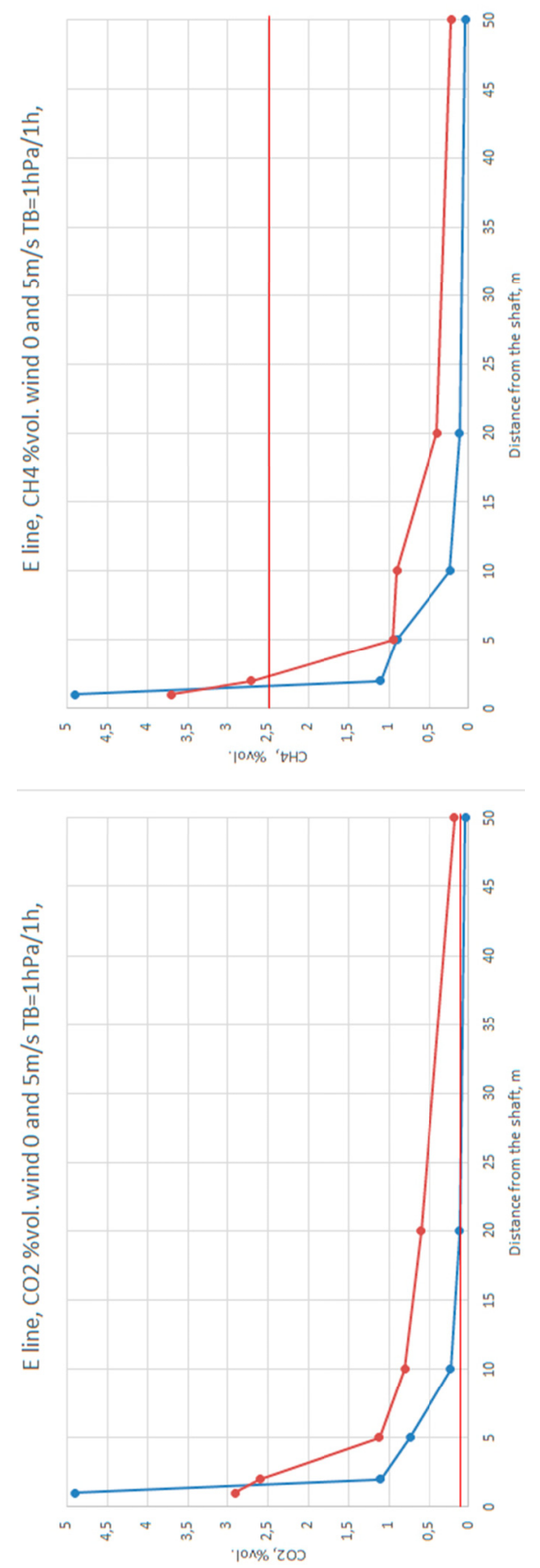

$\sqrt{5}$
0
0
0

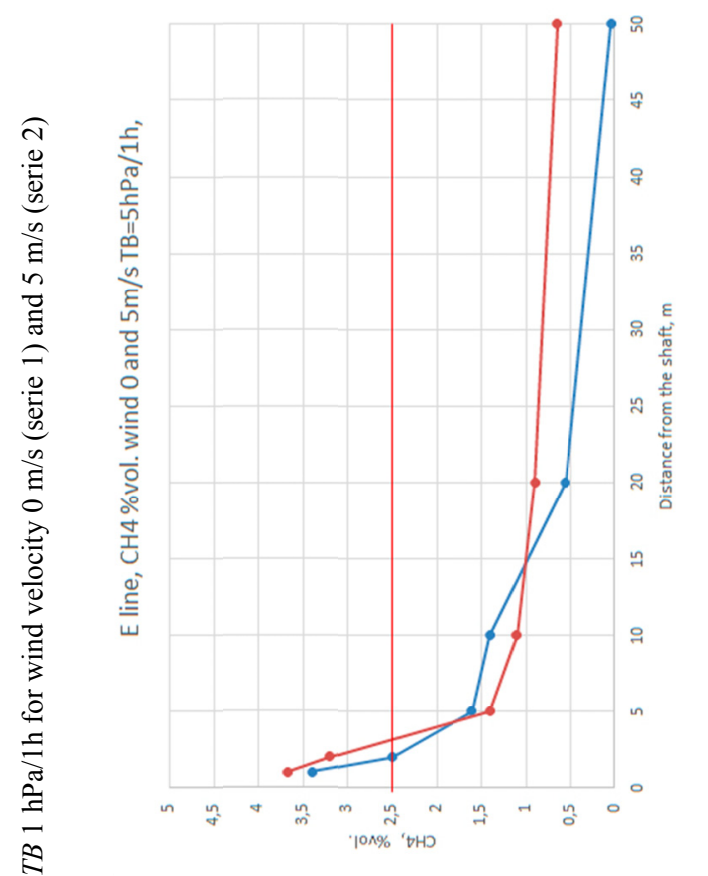

to

(2)

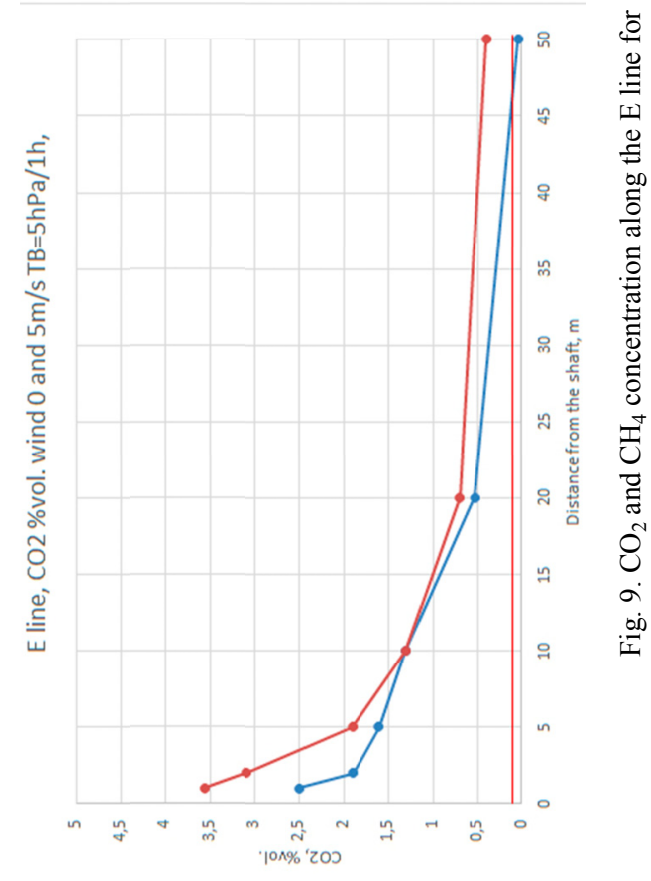


E line, $\mathrm{CO} 2 \%$ vol. wind $5 \mathrm{~m} / \mathrm{s} \mathrm{TB}=5 \mathrm{hPa} / 1 \mathrm{~h}$,

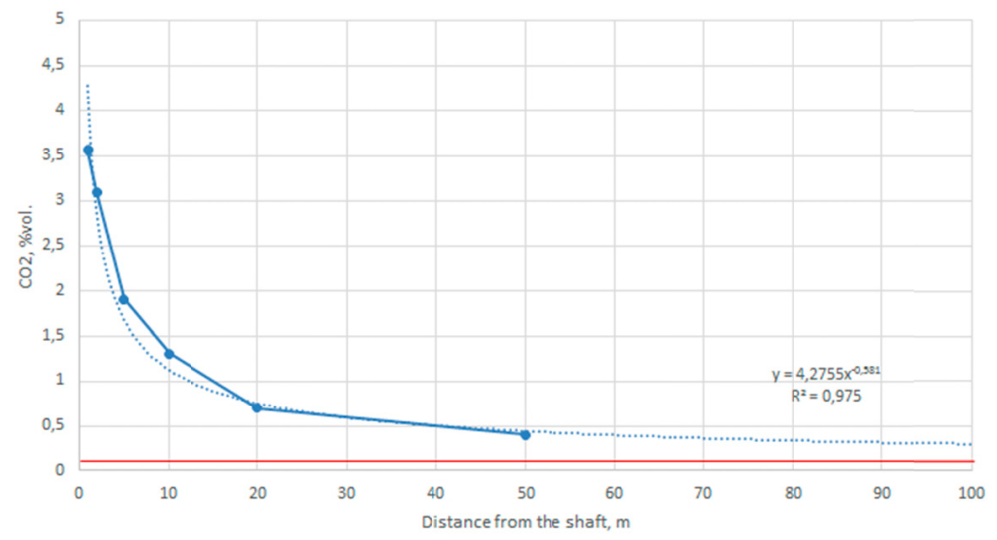

Fig. 10. Concentration of $\mathrm{CO}_{2}$ along the wind direction line (E) for two wind sets and projected $T B=5 \mathrm{hPa} / 1 \mathrm{~h}$

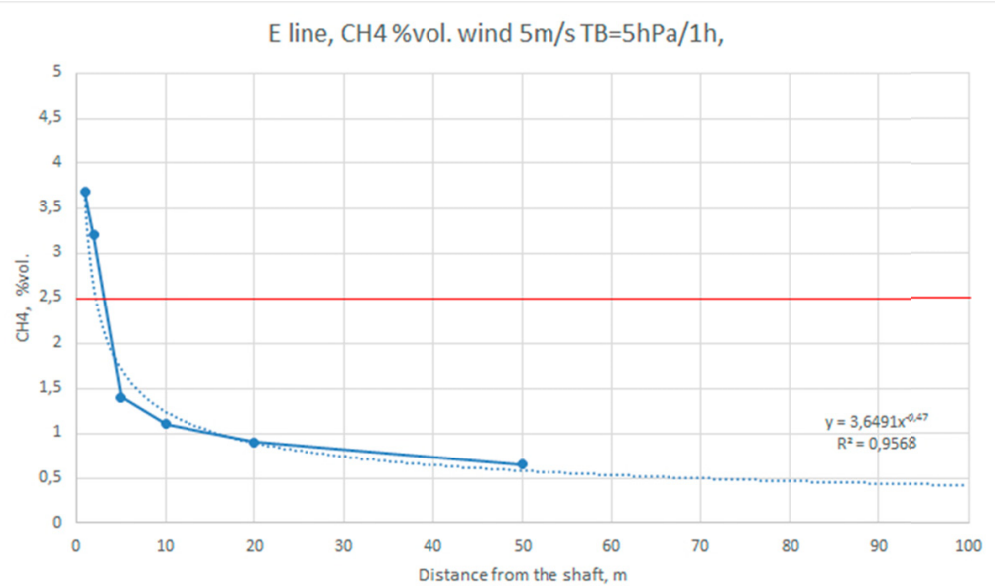

Fig. 11. Concentration of $\mathrm{CH}_{4}$ along the wind direction line (E) for two wind sets and projected $T B=5 \mathrm{hPa} / 1 \mathrm{~h}$

\section{Conclusions}

1. Lack of wind causes a very similar gas distribution along the main four geographical directions $(\mathrm{N}, \mathrm{S}, \mathrm{E}, \mathrm{W})$ and a more intense value of TB results in a higher distance from the shaft for the point where assumed comparison levels $\left(0.1 \%\right.$ vol. for $\mathrm{CO}_{2}$ and $2.5 \% \mathrm{vol}$. for $\left.\mathrm{CH}_{4}\right)$ for both greenhouse gasses may be exceeded. It is up to $45 \mathrm{~m}$ for $\mathrm{CO}_{2}$ and $4 \mathrm{~m} \mathrm{for} \mathrm{CH}_{4}$ (Figs 2-5).

2. Comparison of the influence of wind velocity (Figs 6,7) shows that a westerly wind with velocity set at $5 \mathrm{~m} / \mathrm{s}$ produces a significant gas flow in an easterly direction and higher concentration of the gases along this direction, though a gas is also observed in vicinity of the shaft. Under $T B=5 \mathrm{hPa} / 1 \mathrm{~h}$ and wind velocity $5 \mathrm{~m} / \mathrm{s}$ (Figs 8,9 ), assumed comparison level for $\mathrm{CO}_{2}$ is 
exceeded over $50 \mathrm{~m}$ from the shaft, and for $\mathrm{CH}_{4}$ about $4.5 \mathrm{~m}$ for the shaft. However, at a distance of $50 \mathrm{~m}$ from the shaft the $\mathrm{CH}_{4}$ concentration is still higher than $0.5 \% \mathrm{vol}$.

3. It is possible to determine projection curves (Figs 10,11) for the $\mathrm{CO}_{2}$ and $\mathrm{CH}_{4}$ concentrations along the wind direction line as a result of climate change which leads to more intense pressure drops $(T B=5 \mathrm{hPa} / 1 \mathrm{~h})$. They indicate that both $\mathrm{CO}_{2}$ and $\mathrm{CH}_{4}$ could be detected more than $100 \mathrm{~m}$ from the shaft along the wind direction line.

\section{Acknowledgments}

Appreciations for Mr. Tim Harrell for English proof reading of the text.

\section{References}

Anderson D.A., Tannehill J.C., Pletcher R.H., 1997. Computational Fluid Mechanics and Heat Tranfer [online]. Wyd. 4. Philadelphia: Hemisphere Publishing Corporation.

Annunziatellis A., Beaubien S.E., Bigi S., Ciotoli G., Coltella M., Lombardi S., 2008. Gas migration along fault systems and through the vadose zone in the Latera caldera (central Italy): Implications for $\mathrm{CO}_{2}$ geological storage. International Journal of Greenhouse Gas Control 2, 3, 353-372, DOI:10.1016/j.ijggc.2008.02.003

Bateson L., Vellico M., Beaubien S.E., Pearce J.M, Annunziatellis A., Ciotoli G., Coren F., Lombardi S., Marsh S., 2008. The application of remote-sensing techniques to monitor $\mathrm{CO}_{2}$-storage sites for surface leakage: Method development and testing at Latera (Italy) where naturally produced $\mathrm{CO}_{2}$ is leaking to the atmosphere, International Journal of Greenhouse Gas Control 2, 3, 388-400, DOI:10.1016/j.ijggc.2007.12.005

Bielec-Bąkowska Z., 2007. Występowanie głębokich niżów i silnych wyżów nad Polska (1971-2000). [W:] K. Piotrowicz, R. Twardosz (red.), Wahania klimatu w różnych skalach, przestrzennych i czasowych, Instytut Geografii i Gospodarki Przestrzennej, UJ, Kraków, 65-74.

Branny M., 2003. Numerical simulation of airflow in blind headings ventilated with jest fans. Archives of Mining Sciences 48, 425-443.

Collins M., KnuttiR., Arblaster J., Dufresne J.-L., Fichefet T., Friedlingstein P., Gao X., Gutowski W.J., Johns T., Krinner G., Shongwe M., Tebaldi C., Weaver A.J., Wehner M., 2013. Long-term Climate Change: Projections, Commitments and Irreversibility. [In:] Climate Change 2013: The Physical Science Basis. Contribution of Working Group I to the Fifth Assessment Report of the Intergovernmental Panel on Climate Change [Stocker, T.F., D. Qin, G.-K. Plattner, M. Tignor, S.K. Allen, J. Boschung, A. Nauels, Y. Xia, V. Bex and P.M. Midgley (eds.)]. Cambridge University Press, Cambridge, United Kingdom and New York, NY, USA.

Creedy D.P., 1993. Methane emissions from coal related sources in Britain: Development of a methodology. Chemosphere 26, 1-4, 419-439, DOI:10.1016/0045-6535(93)90435-8.

Czaja P., 2012. Polskie doświadczenia w likwidacji szybów Część 16. Likwidacja szybów głównych kopalni „1 Maja“ —ostrzeżenie i lekcja odpowiedzialności. Wiadomości Górnicze 63, 6, 365-374.

Dziurzyński W., Krach A., Krawczyk J., Pałka T., 2004. Migracja gazów z szybu zlikwidowanej kopalni. Mat. 3 Szkoły Aerologii Górniczej, Zakopane 12-15.10.04, 167-180.

Falarz M., 1997. Ekstremalne wahania ciśnienia atmosferycznego w Krakowie na tle cyrkulacji atmosfery. Materiały Sympozjum Jubileuszowego Polskiego Towarzystwa Geofizycznego „Ekstremalne Zjawiska Meteorologiczne, Hydrologiczne i Oceanograficzne”, 12-14 listopada 1997, IMGW, Warszawa, 32-37.

Grzybek I., 2012. Studium uwarunkowań emisji gazów ze zlikwidowanych kopalń SW części GZW. Bezpieczeństwo Pracy i Ochrona Środowiska w Górnictwie 1-5, 8-10.

Kotarba M.J., Dzieniewicz M., Korus A., Sechman H., Kominowski K. Gogolewska A., Grzybek J., 2002. Mechanism of coalbed gas flux and prediction of gas hazard in the near-surface zone of the Watbrzych Coal Sub-basin. Chapter 13 [in:] Kotarba M.J. (Ed.): Gas hazard in the near-surface zone of the Wałbrzych Coal District caused by coal mine closure: geological and geochemical controls. Society of Research on Environmental Changes "GEOSPHERE", Kraków, 189-212. 
Koźmiński C., Michalska B., 2010. Międzydobowe zmiany ciśnienia atmosferycznego w strefie polskiego wybrzeża Battyku. Przegląd Geograficzny 82, 1, 73-84.

Krause E., 2003. Ksztaltowanie się zagrożenia metanowego w likwidowanej kopalni „, 1 Maja”. Mat. XX Sem. „Metan i inne zagrożenia współwystępujące - teoria i praktyka" NOT-SITG ROP 2003, 29.10.2003 Rybnik.

Lagny C., Lafortune S., Charmoille A., Pokryszka Z., Degrelle F., Kimmel M., 2013. Understanding CO ${ }_{2}$ Gas Production Above a Partly Flooded. Former Coal Mining Area. Procedia Earth and Planetary Science 12, 7. DOI: 10.1016/j. proeps.2013.03.095.

Lewicki J.L., Birkholzer J., Tsang C.-F., 2007. Natural and industrial analogues for leakage of $\mathrm{CO}_{2}$ from storage reservoirs: identification of features, events, and processes and lessons learned. Environ Geol 52:457-467, DOI 10.1007/s00254-006-0479-7.

McGrattan K., Hostikka S., Floyd J., Baum H., Rehm R., Mell W., McDermott R., 2010. Fire Dynamics Simulator (Version 5) Technical Reference Guide, Vol. 1: Mathematical Model [online]. NIST Special Publication 1018-5. Washington: NIST Special Publication.

Nawrat S., 2002. Problemy likwidacji szybów kopalnianych na przykładzie doświadczeń KWK „Morcinek” w aspekcie wybuchu metanu w szybie III. Mat. Szkoły Eksp. Podz. 1, Kraków, 479-493.

National Greenhouse and Energy Reporting (NGER), Act 2007, 2009. National Greenhouse and Energy Reporting (Measurement) Determination 2008, Prepared by the Office of Legislative Drafting and Publishing, Attorney-General's Department, Canberra, http://www.ipcc-nggip.iges.or.jp/public/2006gl/vol2.html

Paulley A., Metcalfe R., Egan M., Maul P.R., Limer L., Grimstad A.-A., 2013. Hypothetical Impact Scenarios for CO 2 Leakage from Storage Sites. Energy Procedia, Vol. 37, 3495-3502, DOI:10.1016/j.egypro.2013.06.240.

Prokop P., 2001. Gas leak effects on environment of Ostrava basin. Proc. of the 7th Inernational Mine Ventilation Congress - Research \& Development Center EMAG, (eds), Kraków (Poland).

Rudakov D.V., Coldewey W.G., Goerke-Mallet P., 2014. Modelling the inflow and discharge from underground structures within the abandoned hardcoal mining area of West Field (Ibbenbüren). [In:] An Interdisciplinary Response to Mine Water Challenges, Sui, W., Sun, Y., and Wang, C.(eds), China University of Mining and Technology Press, Xuzhou, China, 699-705.

Słomka A., 1999. Wentylacja i klimatyzacja pomieszczeń pracy. Wyd. Ośrodek Szkolenia Państwowej Inspekcji Pracy, Wrocław.

Suban A., Petelin S., Vidmar P., 2015. Effect of Gusty Wind on Road Tunnel Safety. Journal of Mechanical Engineering, 61, 7-8, 421-431, DOI:10.5545/sv-jme.2015.2433.

Szlązak N., Obracaj D., Borowski M., 2002. Zagrożenie gazami kopalnianymi w obiektach budowlanych na terenach zlikwidowanych kopalń podziemnych. Przegląd Górniczy 58, 7-8, 42-28.

Trepińska J., 2007. Ciśnienie atmosferyczne. [W:] D. Matuszko (red.), Klimat Krakowa w XX wieku, Instytut Geografii i Gospodarki Przestrzennej, UJ Kraków, 4154.

Ustrnul Z., Czekierda D., 2000. Air pressure extreme during the instrumental observation period in Warsaw. [W:] B. Obrębska-Starkel (red.), Images of Weather of Climate, Prace Geograficzne, UJ 108, 207-213.

Wrona P., 2010a. The method of estimation of gas hazard near abandoned coal mine shaft. Wiadomości Górnicze 5, 287-293.

Wrona P., 2010b. Przeplyw powietrza zrobowego $w$ zlikwidowanych szybach $w$ stanach awaryjnych $w$ świetle badań modelowych. Przegląd Górniczy 12, 148-151.

Wrona P., 2013. Wpływ prędkości powietrza na rozwój pożaru egzogenicznego w wyrobisku górniczym - symulacja w programie Fire Dynamics Simulator (FDS) - Pyrosim. Przegląd Górniczy 7.

Wrona P., Różański Z., Pach G., 2013. Carbon Monoxide Emission from Diesel Engine in Blind Excavation - FDS Simulation. Proceedings of the 13th International Congress on Energy and Mineral Resources (CIERM 2013), ISBN: 978-84-936086-6-8.

Wrona P., 2015. Propozycja nowej metody klasyfikacji zagrożenia gazowego na terenach pogórniczych kopalń węgla kamiennego (Eng. Proposition of a New Method for Classification of Post-Mining Areas due to Gas Hazard), Wiadomości Górnicze 11, 584-593.

Wrona P., Różański Z., Pach G., Domagała L., 2016a. The application of a jet fan for the control of air and methane streams mixing at the excavations cross - the results of numerical simulation. Management Systems in Production Engineering 3, 156-162.

Wrona P., Różański Z., Pach G., Suponik T., Popczyk M., 2016b. Closed coal mine shaft as a source of carbon dioxide emissions. Environmental Earth Sciences 75, article 1139, 2016, DOI: 10.1007/s12665-016-5977-7. 